\title{
Online activism and street harassment: Critical cartographies, counter-mapping and spatial justice
}

OÑati SOCiO-Legal Series, Volume 11 Issue 5 (2021), 1198-1221: YOUTH VIOLENCE: DeESCALATION STRATEGIES AND SOCIO-LEGAL RESPONSES

DOI LINK: HTTPS://DOI.ORG/10.35295/OSLS.IISL/0000-0000-0000-1144

RECEIVED 08 OCTOBER 2019, ACCEPTED 17 JANUARY 2020

\section{BIANCA FILEBORN* (D)}

\section{Abstract}

Social media and activist sites have provided an avenue to contest the dominant framing of street harassment as "trivial" and have sought to make street harassment and its harms visible. To date, digital activism has been analysed and conceptualised in relation to its potential as a counter-public forum that enables collective action and resistance, political mobilisation, "speaking out" and consciousness raising, and as a site of informal or innovative justice. I aim to build on this literature by examining the potential for the activist sites Hollaback!, @catcallsofnyc and @dearcatcallers to function as a form of "counter-mapping", contributing towards broader social justice efforts to disrupt and transform dominant productions of space/place. I examine the tensions created by these digital practices, particularly with regards to whether they disrupt the production of space/place or, rather, reinforce urban space as a gendered "threatscape".

\section{Key words}

Street harassment; digital criminology; activism; critical cartography; crime mapping

\section{Resumen}

Algunas redes sociales y sitios web de activistas han constituido una vía de contestación al marco dominante que considera el acoso callejero como algo "trivial"; y han procurado visibilizar el acoso callejero y sus perjuicios. Hasta la fecha, se ha analizado y conceptualizado el activismo digital en relación con su potencial como contraforo público que posibilita la acción y resistencia colectivas, la movilización política, "alzar la voz" y concienciar, y como lugar de justicia informal o innovadora. Me propongo contribuir a esta literatura realizando un análisis del potencial de los sitios web activistas Hollaback!, @catcallsofnyc y @dearcatcallers para funcionar como "contraperfilado geográfico", contribuyendo a ampliar la justicia social y perturbar y

\footnotetext{
* Lecturer in Criminology, School of Social and Political Sciences, University of Melbourne, Australia. Email address: biancaf@unimelb.edu.au. Phone: +61 (0) 383442916.
} 
transformar producciones dominantes de espacio/lugar. Examino las tensiones creadas por dichas prácticas digitales, sobre todo en torno a la cuestión de si perturban la producción de espacio/lugar o si, más bien, refuerzan el espacio urbano como escenario de amenaza de género.

\section{Palabras clave}

Acoso callejero; criminología digital; activismo; cartografía crítica; cartografía de la delincuencia 


\section{Table of contents}

1. Online activism and street harassment: critical cartographies, counter-mapping and

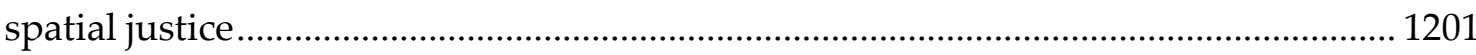

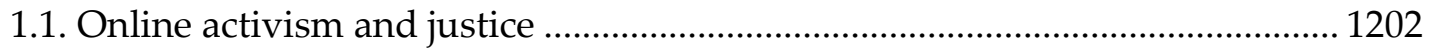

1.2. Critical cartographies and counter-mapping..................................................... 1203

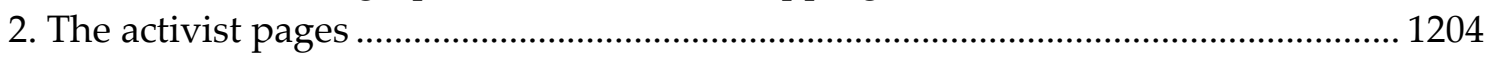

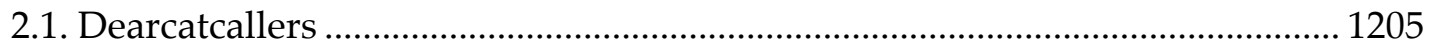

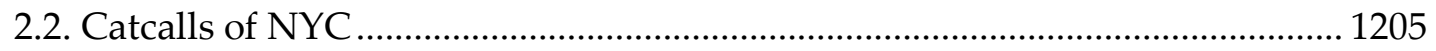

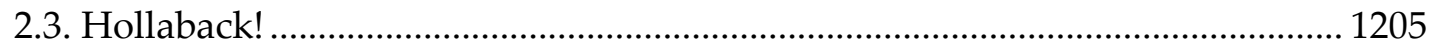

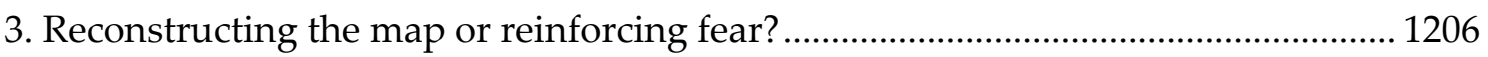

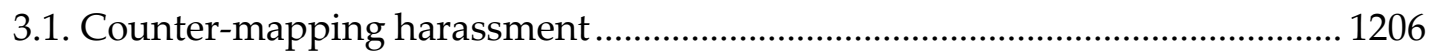

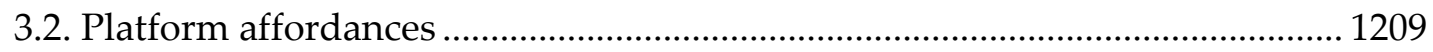

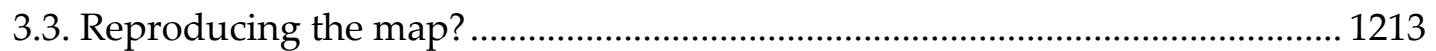

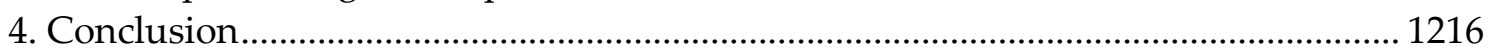

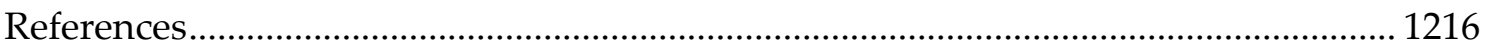




\section{Online activism and street harassment: critical cartographies, counter- mapping and spatial justice}

The development of Web 2.0 revolutionised how aspects of contemporary political activism are undertaken. Web 2.0 platform affordances have created modes of participation that span geographic and temporal contexts, while the interactive and usergenerated features are often credited as having "democratised" the web (Bittner et al. 2013, Bittner 2016). These features have facilitated the development of online "counterpublics" - digital spaces in which dominant social, cultural and political norms can be contested and disrupted (Salter 2013). Online activism has been crucial in contemporary feminist activism and political mobilisation, with street harassment being one issue that has featured heavily (Fileborn 2014, 2017, Mendes et al. 2019, Fileborn and Loney-Howes 2020). This has included recent efforts to map women's and girl's experiences of safety and wellbeing in public space (Plan International 2018), and the proliferation of sites aimed at documenting and challenging the occurrence of street harassment, such as Hollaback!, Everyday Sexism, and HarassMap among many others.

Street harassment is an 'umbrella' term capturing a range of intrusive and unwanted behaviours in public space. The term itself is contested, with scholars such as Fiona VeraGray (2016) promoting the use of the more inclusive conceptualisation "men's intrusions". While I both acknowledge and agree with the limitations of "street harassment" (as not all encounters occur on the "street", and not all are experienced as "harassment" per se), I continue to use this term due to its broader cultural recognition, though I occasionally interchange it with terms such as public intrusion. Typically, street harassment includes actions such as catcalling, staring, wolf-whistling, following someone, uninvited or unwanted comments, and so forth. It is often, but not always, sexual in nature, and frequently intersects with other forms of abuse relating to race (Davis 1994, Nielsen 2000, Fogg-Davis 2006), transphobia (Fileborn 2018), sexuality (Mason 1993, Fogg-Davis 2006), disability and so forth. Given the diverse array of actions that constitute street harassment, it may be more productive to view these actions through their function and impacts, rather than their form (Fileborn and Vera-Gray 2017).

Research consistently demonstrates that women begin experiencing street harassment during late childhood and early adolescence, though older women and LGBTQ+ people are by no means immune (Johnson and Bennett 2015, Vera-Gray 2016). Despite the prevalence and frequency with which street harassment occurs, and its welldocumented impacts on the lives and freedom of those who experience it (Johnson and Bennett 2015, Plan International and OurWatch 2016, Vera-Gray 2016, 2018, Fileborn 2017, Plan International 2018), public harassment continues to be dismissed as "trivial" or "complementary" behaviour and heavily contested as a form of sexualised harm. So thorough is the dismissal of street harassment that it has been termed the "harm that has no name" (Davis 1994). Yet, research to date contests this construction of harassment as "trivial", "minor" or "complimentary". For example, encounters of street harassment generate fear, anger and other negative affective and emotional states (Kissling 1991, Tuerkheimer 1997, Lenton et al. 1999), and visceral corporeal responses such as anxiety, nausea and depression. 
Importantly in the context of this paper, street harassment is implicated in the production of space/place and geographies: it is a practice that produces public spaces as being "for" cisgender, white, heterosexual men (Fileborn 2020). Likewise, street harassment shapes and delimits how women and queer people move through and inhabit their bodies within public spaces (Vera-Gray 2016, 2018, Fileborn 2020). As a result of street harassment - and its potential to foreshadow the threat of "something worse" happening - victims may avoid certain areas at particular times, avoid being alone in public space, or engage in a broad array of "protective" routines in order to feel safe in public spaces (Laniya 2005, Dhillon and Bakaya 2014, Johnson and Bennett 2015, Vera-Gray 2018). However, these impacts can occur with differential intensities depending upon the context of the harassment (Fairchild 2010), and the social and cultural location of the victim (Kern 2005). Additionally, the impacts of street harassment are often cumulative in nature, and lived alongside other experiences of violence, abuse and harassment - sexual or otherwise (Vera-Gray 2016, Ahmed 2017, Fileborn and VeraGray 2017).

Social media and activist sites have provided an avenue to contest the dominant framing of street harassment as "trivial" and have sought to make street harassment and its harms visible. To date, digital activism has been analysed and conceptualised in relation to its potential as a counter-public forum that enables collective action and resistance, political mobilisation, "speaking out" and consciousness raising, and as a site of informal or innovative justice (see Fileborn and Loney-Howes 2020 for an overview). In this work, I aim to advance this literature by situating these activist sites as a form of "countermapping", contributing towards broader social justice efforts to disrupt and transform dominant productions of space/place. I examine the tensions created by these digital practices, particularly with regards to whether they disrupt the production of space/place or, rather, reinforce urban space as a gendered "threatscape" in which women and queer communities are responsibilised for managing their own safety. In order to do so, I first turn to the extant literatures on online activism and justice, and counter-mapping. I then undertake a purposive case study analysis of three contemporary street harassment activist efforts with an online presence: Hollaback!, and the Instagram pages @catcallsofnyc and @dearcatcallers. I argue that while each of these sites can be conceptualised as forms of counter-mapping, working to disrupt and contest dominant framings of both crime and public space, they simultaneously function in complex and contradictory ways that reify dominant power relations.

\subsection{Online activism and justice}

A burgeoning body of literature has established how victim-survivors of sexual violence harness digital media as an informal justice mechanism (Salter 2013, Fileborn 2014, 2017, Powell 2015). Feminist criminological research illustrates the extent to which the formal criminal justice system (CJS) is often unable or unwilling to provide a sense of justice to victim-survivors, in many cases functioning as a site of retraumatisation instead (Herman 2005, Clark 2010, 2015, McGlynn 2011). For some forms of sexualised violence such as street harassment, there is little recourse through the formal justice system (Fileborn 2017). Resultantly, there is an increased focus on developing innovative and informal justice responses to sexual violence that either sit outside of or operate differently to the mainstream system. In particular, feminist scholarship has focused on 
identifying survivors' justice "needs" or "interests", and in formulating justice mechanisms that are responsive to these needs (Daly 2014).

Digital spaces represent one potential avenue for achieving justice outside of the formal CJS. The potential for digital spaces to function as counter-publics opens up possibilities for meeting at least some victim-survivors' justice interests (Salter 2013, Fileborn and Loney-Howes 2020). Counter-publics enable survivors to challenge mainstream justice responses to sexual violence, and to disrupt dominant discursive constructions of this violence, which are typically mired in rape myths and misconceptions (Salter 2013). In relation to street harassment, digital platforms have been used to challenge the notion that it is a "trivial" or "minor" occurrence, particularly through facilitating collective disclosures that give weight to individual encounters (Fileborn 2017). In other words, digital spaces can work to "give voice" to victim-survivors' experiences, an important element of survivors' justice needs. The affordances of digital spaces - such as their collective and interactive nature - means that they can function as sites of belief and validation (Fileborn 2017, Mendes et al. 2018, O'Neill 2018). However, the extent to which digital spaces are able to fulfil survivors' needs is varied, and digital spaces can also amplify the harms of disclosure, as well as being sites of violence in and of themselves (Fileborn 2014, 2017, Henry and Powell 2015, Powell 2015, Fileborn and Loney-Howes 2020).

The point here is not to provide an exhaustive overview of the ways in which digital spaces may or may not work to fulfil survivors' justice needs. Rather, it is to illustrate that most literature to date has considered the role of these platforms in responding to justice needs on an individual level (with some focus on consciousness-raising and collective justice). There has been comparatively little focus on the ways in which these sites might contribute towards broader social justice efforts, and especially towards challenging dominant productions of space/place. It is in this vein that I turn to consider the potential for digital street harassment activism to function as a form of countermapping, drawing on theoretical contributions from critical cartography.

\subsection{Critical cartographies and counter-mapping}

Critical cartography and counter-mapping are based on the premise that the mapping and representation of space is never neutral. "Critical cartography" refers to the body of theoretical and conceptual work that seeks to disrupt and critique conventional, positivist approaches to the construction and interpretation of maps, while "countermapping" is a form of alternative mapping praxis that seeks to "reframe the world (...) to articulate alternative, subversive and marginalised interests" (Kindynis 2014, p. 222; see also Crampton and Krygier 2005, Kitchin and Dodge 2007, Dalton and Mason-Deese 2012, Allen and Queen 2015, Kim 2015, Maharawal and McElroy 2018). Rather than functioning as neutral representations of space, maps are always already imbued with and reinscribe particular interests, epistemologies or ways of "knowing" and representing the world, and relations of power (Kitchin and Dodge 2007, Crampton 2009, Dalton and Mason-Deese 2012, Bittner et al. 2013, Kindynis 2014, Allen and Queen 2015, Bittner 2016) Notably, traditional, positivist approaches to mapping produce spaces as fixed, geographical points that are stable and "knowable", rather than as contested, in flux, and constantly in the process of being (re)produced (McLafferty 2005, Kitchin and Dodge 2007, Bittner et al. 2013). 
Theo Kindynis (2014, p. 222) has argued that despite the centrality of maps and "crime mapping" to the work of criminologists and criminal justice agencies, "their production and application remains largely superficial and uncritical" (see also Hayward 2012, Heiden 2018). Namely, traditional criminological approaches to crime mapping have come to this practice from a positivist lens: as a "neutral" practice that simply represents the world as it is, treating the definition, detection and recording of crime as value-free and objective processes (Hayward 2012, Kindynis 2014, Heiden 2018; see Bittner et al. 2013 in relation to cartography more generally). Criminologists have, for the most part, tended to treat crime mapping as simply "points on a map", with minimal attention paid to the social and cultural production of space and place. This approach is perhaps most aptly demonstrated through the preoccupation with mapping "hotspots" of crime, with crime constructed through a series of disconnected geographic points, divorced from the complex, dynamic and relational nature of lived experience (Hayward 2012, Kindynis 2014).

Indeed, in many respects the work presented here forms a response to Kindynis' call for criminologists to engage critically with cartographical practices - particularly those afforded by digital technologies, or "web 2.0 cartographies" (Bittner et al. 2013, p. 938; see also Bittner 2016, Reiz et al. 2017) - and to interrogate their potential "as a vehicle for social and political intervention" (Kindynis 2014, p. 222). This may be achieved through the practice of "counter-mapping". As noted above, counter-mapping involves the use of mapping practices by oppressed and marginalised groups in order to contest the dominant social and political order as expressed in and through space. Countermapping can also involve styles of or approaches to mapping that are creative or innovative, and develop different ways of seeing or representing the world (Kindynis 2014). Similar to how the counter-public nature and user-generated affordances of digital spaces have enabled them to function as sites of informal justice, these features also lend themselves to the art of counter-mapping (Crampton and Krygier 2005, Bittner et al. 2013, Kindynis 2014, Bittner 2016). Bittner and colleagues (2013) note that Web 2.0 affordances allow for the construction of maps and other spatial data by those situated outside of the "established and exclusive limits of academic geography and institutionalized state-run (...) cartography" (Bittner et al. 2013, p. 936; see also Crampton and Krygier 2005). Additionally, Bittner and colleagues (2013, p. 938) suggest that online mapping exercises neatly illustrate the fluid and emergent nature of cartography, with digital mapping practices "continually produced and reproduced, re-worked, re-published, mashed-up and updated". In light of this, I move now to examine the potential of digital street harassment activism to function as a form of counter-mapping.

\section{The activist pages}

In order to examine the extent to which digital activism for street harassment might function as a form of counter-mapping, this article draws on a purposive case study analysis of three contemporary activist sites: @dearcatcallers (Instagram), @catcallsofnyc (Instagram) and Hollaback! (a standalone webpage). Case study analysis was adopted as a method here to undertake an in-depth analysis of digital street harassment activism (Swanborn 2010, Bartlett and Vavrus 2017, p. 40). In taking this approach, my aim was to develop some initial and tentative insights into the role of digital activism as a form of counter-mapping, given the absence of any prior research on this topic. 
The three activist pages were selected for analysis as they represent different approaches to digital activism and, subsequently, counter-mapping. This allowed for a rich and nuanced analysis of both the potential for these practices to function as a form of countermapping, but also insight into the diverse limitations of digital activism as countermapping. These cases were selected as they were all publicly available and explicitly intended for public engagement (Markham and Buchanan 2012): as detailed below, all sites had the express aim of generating discussion of and attention to the issue of street harassment. Each of the activist sites was analysed with an emphasis on how public spaces and street harassment were being (re)produced, and the affordances of the site and techniques used in constructing public space and street harassment (for example, the use of images, text, and interactive mapping). Although I do draw on examples of text from each site, this work did not (and was not intended to) undertake a detailed content or discourse analysis of each site, especially given the large number of posts to @catcallsofnyc and Hollaback! While the selection of these case studies allowed for a deep analysis, they are not intended to provide any "generalisable" insights into countermapping and digital activism. The following section provides a brief overview of each of the case studies, before moving on to consider their potential as a form of countermapping.

\subsection{Dearcatcallers}

The @dearcatcallers Instagram page was established in 2017 in order to "create awareness about the objectification of women in daily life" (@dearcatcallers 2017). The page was founded by Noa Jansma, a 20-year-old woman from Amsterdam, and aimed to challenge the invisibility of street harassment. Jansma posted a photo of herself with the men who "catcalled" her every day for one month (typically also accompanied by a text caption briefly outlining the incident), with the "objectified and the object (...) assembled in one composition", which "represents the reversed power ratio which is caused by this project" (dearcatcallers 2017). @dearcatcallers also encouraged others to post their experiences using the \#dearcatcallers hashtag.

\subsection{Catcalls of NYC}

This Instagram account encourages followers to "DM" (direct message) incidents of catcalling in New York City (with similar pages having been established for other urban centres, such as London). Submissions typically provide a detailed explanation of the incident, including comments and actions engaged in by the perpetrator, and an indication of the location. The @catcallsofnyc team then write "chalk graffiti" on a public footpath, with this graffiti typically consisting of a quote of what the perpetrator said, the @catcallsofnyc Instagram account, and \#StopStreetHarassment. A photo of the chalk graffiti and screenshot of the original submission are then posted to the Instagram page.

\subsection{Hollaback!}

Hollaback! is the "original" anti-street harassment website. Created in 2005, the Hollaback! Movement encourages those who have experienced, witnessed or intervened in street harassment to document the incident. The website provides an interactive Google map that allows users to drop pins on the location of the harassment. Submissions can include written descriptions of the incident, as well as photographs 
(though submissions are typically text-based). Readers can express their support for others by hitting the "got your back" button for individual submissions. Hollaback! aims to "break the silence" surrounding street harassment by harnessing digital technologies, and also includes resources, links to support services, and tips for engaging in bystander intervention.

\section{Reconstructing the map or reinforcing fear?}

In the remainder of this article, I critically examine whether - and the extent to which these activist sites constitute a form of counter-mapping. That is, I consider whether they can be understood as disrupting and challenging the dominant ordering or "striation" of public space (Fanghanel 2019), and the extent to which these digital practices might destabilise traditional criminological and criminal justice approaches to the mapping of crime.

\subsection{Counter-mapping harassment}

I suggest that all three activist sites can be considered as a form of counter-mapping in at least some respects. As outlined earlier, street harassment is frequently constructed as a minor and trivial form of sexualised violence. Notably, many iterations of street harassment are not regulated through the formal criminal justice system, although this is also a dynamic situation with numerous jurisdictions - including France, Belgium, and some states within the US - having recently introduced legislation specifically addressing street harassment (Fileborn 2017, Stop Street Harassment n.d.). Even where legislation or other forms of regulation are in place, street harassment appears to be only rarely reported to the criminal justice system. Australian research illustrates that victims of street harassment rarely report to police, are unsure as to whether street harassment meets the threshold for a criminal offence, and often felt there was little to be achieved by reporting, given the often-fleeting nature of these encounters (Fileborn and VeraGray 2017). Additionally, the harms of street harassment often lie in the cumulative nature of these incidents, making it difficult to respond to through the mainstream justice system which focuses on discrete incidents and perpetrators (Fileborn and VeraGray 2017). All of this is to say that street harassment is rarely "counted" through any official measures of crime or victimisation: it is a form of harm that has not typically been represented (or made "knowable") through traditional approaches to mapping the relationships between crime and space, which typically rely on state definitions and reports of crime (Kindynis 2014).

In this sense, all three sites clearly function as a form of counter-mapping in that they all work to document a form of sexual (and other) violence that is largely ignored, uncounted, and not responded to through official criminal justice mechanisms. They reflect what Kim (2015, p. 215) terms "testimony maps", which work to "challenge our understanding of what is the status quo through re-presenting situations, often injustices or overlooked phenomena". Kindynis suggests that counter-mapping can help to promote social justice "by making visible that which otherwise goes unseen" (Kindynis 2014, p. 236). As such, practices that visibilise the "harm that has no name" (Davis 1994) or "unspeakable" (Fileborn 2018) harms of street harassment constitute countermapping by making experiences visible on the individual, incident-based and collective level. Importantly, all three sites work to challenge and disrupt the normalisation of 
street harassment by positioning it (and the actions of perpetrators) as a "problem". This is illustrated through statements made on each of the sites articulating their intended aims or purpose. For instance, the "about" section of the @dearcatcallers Instagram profile simply states, "it's not a compliment", contesting the commonplace assumption that street harassment is merely well-intended, flirtatious behaviour, if perhaps poorly executed. Likewise, @dearcatcallers (2017) aims to "create awareness about the objectification of women in daily life", based on the assumption that the general public lack an understanding of the frequency and harms of the behaviour.

In contrast, @catcallsofnyc simply asks followers to "DM [direct message] stories of harassment, location in NYC \& we will share". While many posts contain a direct quote of the story shared by a follower, accompanied by an image of the sidewalk chalk graffiti, @catcallsofnyc occasionally also provide commentary in the text challenging and denouncing the actions of perpetrators. For example, one post displays the words of a perpetrator "you don't wanna smile for me" in chalk graffiti, accompanied by text below the image stating: "the consensus is no, we don't want to smile for you. Comment below with what you want to say to a man on the street who tells you to smile" (which had generated 61 comments at the time of writing; see Figure 1). Another post describes a submission where a woman reported being verbally harassed while visiting her grandmother in hospital. An image of the perpetrator's words - "good thing we're at a hospital because you're killing me with that ass!" - is accompanied the story submitted by the follower, as well as additional text from the @catcallsofnyc account stating that:

I honestly can't stress this enough to people on here trying to learn why catcalling is bad/those of you who aren't convinced that it's always a bad thing... we want to walk in peace, we want to go about our days in peace, we want to visit our family members at the hospital in peace!! Show us the utmost respect as we go through our day by NOT commenting on our appearance. \#stopstreetharassment.

By making such experiences visible, and in framing them as harmful, this contests dominant discursive constructions of street harassment as "trivial" and repositions it as an action requiring intervention and response, whether from the state or bystanders. The commentary provided by @catcallsofnyc here not only draws attention to the dominant framing of harassment but seeks to disrupt this construction through offering up an alternative vision for the gendered production of space/place, one that is centred on "peace" and mutual respect, rather than objectification. The Hollaback! website is perhaps most explicit in its call to action, describing themselves as "a movement to end harassment in public spaces". Hollaback!, like the other activist sites, is centred on the power of sharing one's story in order to shift discursive constructions: "by sharing your story, you change the way people talk about and understand harassment" (NYC Hollaback n.d.). In encouraging users to share their story, the site reminds us "you're not alone. We believe you. We've got your back". Such comments work to challenge and disrupt dominant myths and misconceptions about sexual violence more broadly, namely that survivors (particularly women) are prone to exaggeration, misinterpretation and lying. In stating that "you're not alone" the site works to situate individual experiences within a broader collective, functioning as a form of consciousness-raising (Fileborn 2017, Serisier 2018, Loney-Howes 2019). 


\section{FIGURE 1}

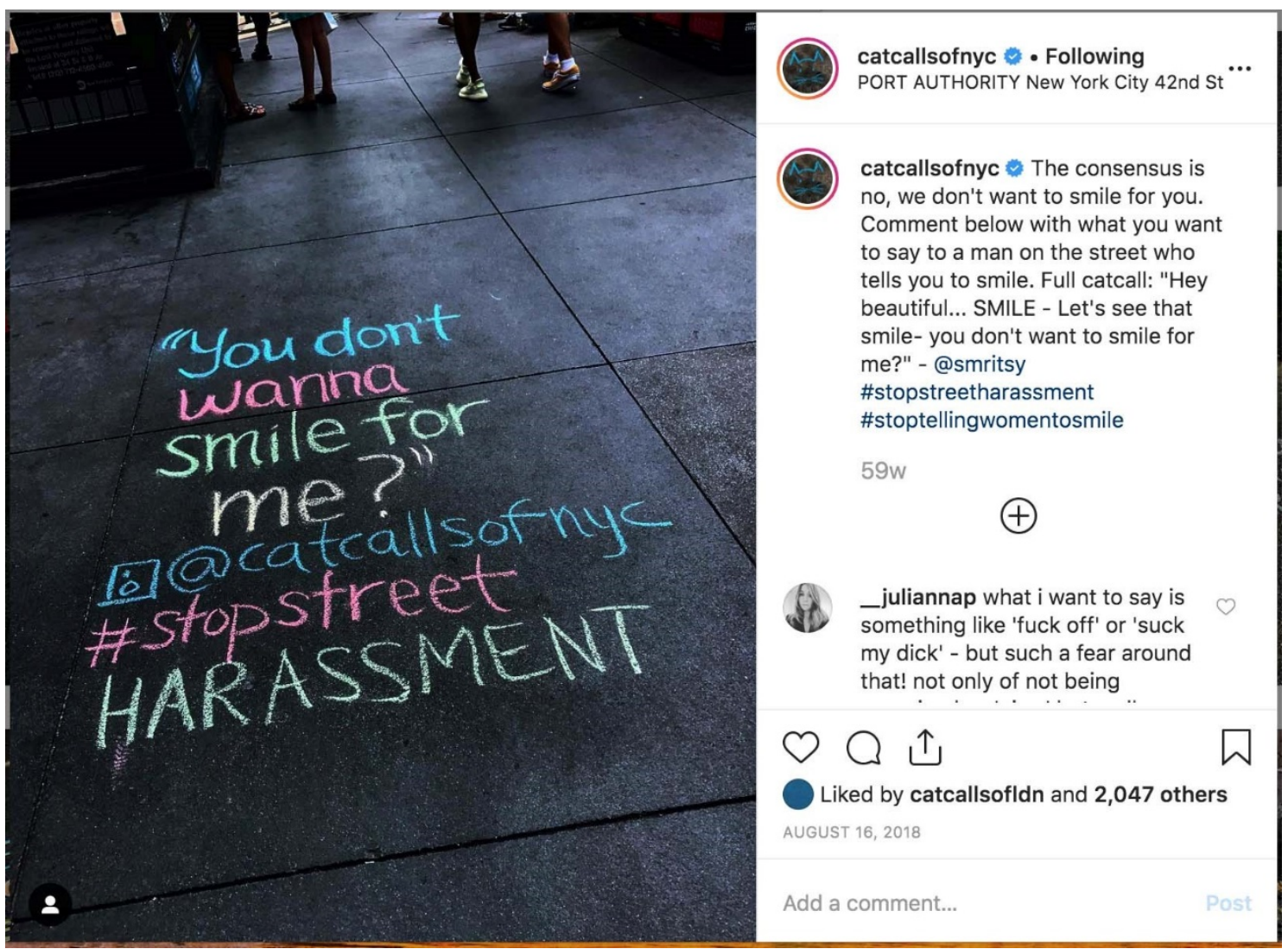

Figure 1. @catcallsofnyc.

These accounts all aim to "give voice" to the experiences of oppressed and marginalised groups, albeit to varying extents (something that I address further in the limitations section; see also Serisier 2018 for a broader critique of the politics of "speaking out"). Street harassment can be conceptualised as an expression of power: a means of (re)producing and (re)inforcing gendered, racialized and other power relations in public space. It is an act that is deeply implicated in perpetuating broader systems of inequality, and of the exclusion and marginalisation of (particularly) women and LGBTQ+ communities in public space. Street harassment works to mark the boundaries of belonging and inclusion within public space, communicating that this space is "not for" those on the receiving end of this behaviour: it produces victims as "being-for-others" in the public realm (Vera-Gray and Fileborn 2018). As such, these activist sites function to disrupt dominant power relations by creating a space to represent and express the experiences of oppressed groups. To return to Kindynis, these are digital spaces which enable us "to articulate alternative, subversive and marginalised interests" (Kindynis 2014 , p. 222) in a way that contests the dominant construction of public space.

Arguably, this component of activist sites as counter-mapping aligns with features that have been documented in the burgeoning work on online justice for various forms of sexual violence, including street harassment (Salter 2013, Fileborn 2014, 2017, Powell 2015). Each of the activist sites gives survivors the ability to share their experiences in their own words - to "give voice" to what happened in a way that is meaningful to them. Likewise, the counter-public nature of digital spaces enables them to challenge and disrupt dominant constructions of street harassment, as the discussion here has begun 
to illustrate. Further, these practices also have distinctly spatial and geographical features, in that they function to map and (re)present public spaces, as well as working to challenge and disrupt the gendered production of public spaces. However, the extent to which (and how) these sites function as counter-maps is also shaped by the particular affordances of each platform.

\subsection{Platform affordances}

Platform affordances refers to "the potential actions an artefact or technology enables" (Wood 2017, 80). Platform affordances shape the extent and ways in which these activist accounts may function as counter-mapping. As noted earlier, one defining feature of counter-mapping can include innovative or creative ways of representing space that asks us to view the world differently in some respects (Kindynis 2014). The ability to engage in innovative mapping practices is opened up through platform affordances, as I illustrate further in this section. These sites must likewise be situated within Web 2.0 cartographies, with technological advances supporting "dramatic changes in the sociotechnological generation of maps and spatial data" by creating the opportunity for participatory mapping techniques (Bittner 2016, p. 35). As Hollaback! (n.d) note, "the explosion of mobile technology has given us an unprecedented opportunity to end street harassment", highlighting how the complex entanglement and embedding of digital technologies within our social lives has enabled this form of counter-mapping (McLafferty 2005, Bittner et al. 2013, Stratton et al. 2017). It is the ubiquitous technohuman assemblage of the smart phone, for example, that enables @dearcatcallers to readily capture and share images of her perpetrators as she navigates through public space.

Firstly, these platform affordances and the entanglement of the digital with social and cultural practices generates the potential for these sites to respectively function as counter-maps: their interactive, user generated nature means that in all cases, public space is being "mapped from below" by those who would not otherwise have had the power or authority to produce "official" crime maps (Crampton and Krygier 2005, Kindynis 2014, Kim 2015, Bittner 2016). Indeed, this potentiality is further heightened by the aforementioned exclusion of street harassment from traditional crime mapping exercises: digital cartographies present the possibility of mapping and spatially representing a form of harm that is currently excluded from official crime data in virtually all jurisdictions. In theory, at least, anyone is able to share experiences of street harassment through Hollaback! and @catcallsofnyc provided they live in the designated geographical area (though this already points to the processes of silence and exclusion these sites may collectively, if unintentionally, perpetuate. Rural and regional spaces remain largely untouched through these efforts). These sites work to produce a "pinboard pastiche" or patchwork of maps, constituted through the contributions of multiple users' submissions in a continually evolving way (Kitchin and Dodge 2007, Bittner et al. 2013, Salovaara 2016). In this sense, public spaces and the phenomenon of street harassment are always already being reproduced in a fluid and dynamic way through the iterative and collaborative nature of these sites. @dearcatcallers is perhaps an exception here, given that it aimed to document the experiences of one individual in a time-bounded way. Even still, as the Instagram account remains open to view and for 
users to leave comments, the meaning(s) attached to this particular site may continue to evolve over time as different users engage with it.

There are other affordances of these sites lending themselves to the innovative mapping or representation of space. For instance, @catcallsofnyc Instagram "maps" spaces in a manner that extends beyond simply "points on a map". The practice of chalk writing submissions disrupts and redefines physical spaces by making the often-fleeting encounters of harassment visible to other members of the public (albeit also in a fluid and temporary way, given the impermanence of chalk - perhaps making it a particularly fitting medium). The chalk writing constructs a temporary map of incidents in public space - this happened here. The practice of posting images of the chalk writing online creates a digital repository that maps these incidents in a comparatively more "permanent" way, with public space represented through the words and actions of perpetrators.

These digital repositories, and the affordances of Instagram, allow both @catcallsofnyc and (particularly) @dearcatcallers to express the cumulative nature of street harassment, and the ways in which these encounters are insidious and lived alongside one another. The timeline function of Instagram allows posts to be viewed collectively, in chronological order in which posts were made. By visiting the @dearcatcallers page, for example, street harassment is represented to the viewer through a series of 21 incidents encountered by Jansma over the course of a month, visually mapping its repetitive and mundane occurrence. Arguably, this is something that is often missed in traditional, "static" crime maps, which tend to produce crime as a series of individual, disconnected incidents, eliding the cumulative and progressive nature of lived experience. Similarly, the sheer number of submissions made to both Hollaback! and @catcallsofnyc draws attention to the pervasive and shared nature of this experience: street harassment becomes mapped through collective disclosures, rather than presented as rare, isolated incidents.

The affordances of Instagram also allow @dearcatcallers and @catcallsofnyc to shift the focus to the perpetrators of harassment, disrupting "usual" modes of disclosure and justice seeking online, which tend to centre the narratives of victim/survivors (Fileborn 2014, 2017, O'Neill 2018, Serisier 2018). Thus, rather than mapping harassment through a series of accounts of victimisation, public space is represented in and through the images and words of perpetrators. Posts made by @catcallsofnyc, for example, consist exclusively of the words of perpetrators. The subverts the "usual" genre conventions of "speaking out" about sexual violence, which tend to emphasise the suffering and vulnerability of the victim-survivor (Serisier 2018). @dearcatcallers also draws on the affective and emotive affordances of Instagram to visually express her displeasure at her perpetrators (see Figure 2), captured in the stern, unsmiling face that appears in each image alongside her (often seemingly clueless) perpetrators (perhaps also a visual retort to the common catcall of "smile" or "cheer up" - see Vera-Gray and Fileborn 2018). Her experiences of public space are thus mapped through her encounters with perpetrators, with her displeased facial expression simultaneously contesting normative constructions of harassment as "trivial". This practice subverts the "gaze" of street harassment, with the perpetrators (re)positioned as the objects of attention and appraisal, and Jansma reclaiming her agency. 


\section{FIGURE 2}

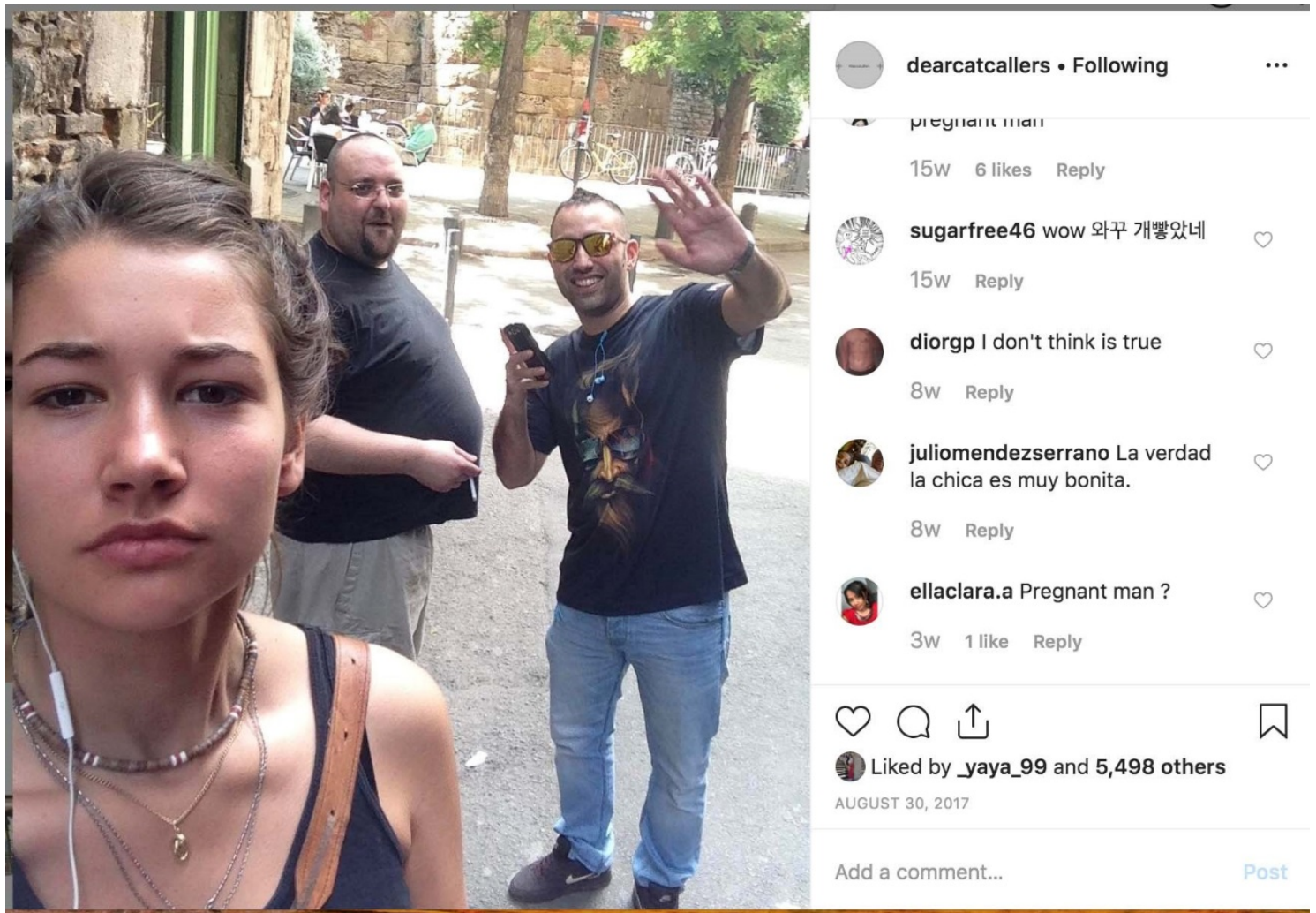

Figure 2: @dearcatcallers.

On the surface, Hollaback! perhaps most closely resembles traditional "hot spot" approaches to crime mapping (and does indeed retain some of these elements, as I discuss momentarily), which as Kindynis has argued serve to (re)produce both crime and space in a superficial, positivist way. This is illustrated in Figure 3, with both the Hollaback! Google map appearing to reproduce individual incidents in a decontextualized and fixed manner. However, the affordances of the Hollaback! site enable it to simultaneously function as a form of counter-mapping in several respects. Firstly, although it involves locating literal "points on a map", Hollaback! is making visible a form of harm that is not typically understood as such, and certainly not captured in mainstream measurement of "crime" as outlined earlier. In doing so, Hollaback! functions to contest dominant discursive constructions of "what counts" as a harm that is "worthy" of being counted and mapped. Further, this subverts traditional epistemologies and ontologies of crime and harm: we come to know what crime/harm is not through the authoritative pronouncements of criminal justice actors, but through the lived experience(s) of women and queer people. Secondly, Hollaback! extends beyond just providing decontextualized points on a map by also giving voice to participants' narratives and experiences of harassment, helping to circumvent the tendency for traditional crime maps to negate the complexity of lived experience (Kindynis 2014). Maharawal and McElroy (2018, p. 385) similarly point to the importance of including, in their case, life histories of tenants evicted from gentrified areas of San Francisco (as well as a host of other activist efforts), with these contributions adding rich context and "stories of loss as well as resistance" alongside a more conventional "points on a map" approach to counter-mapping. 


\section{FIGURE 3}

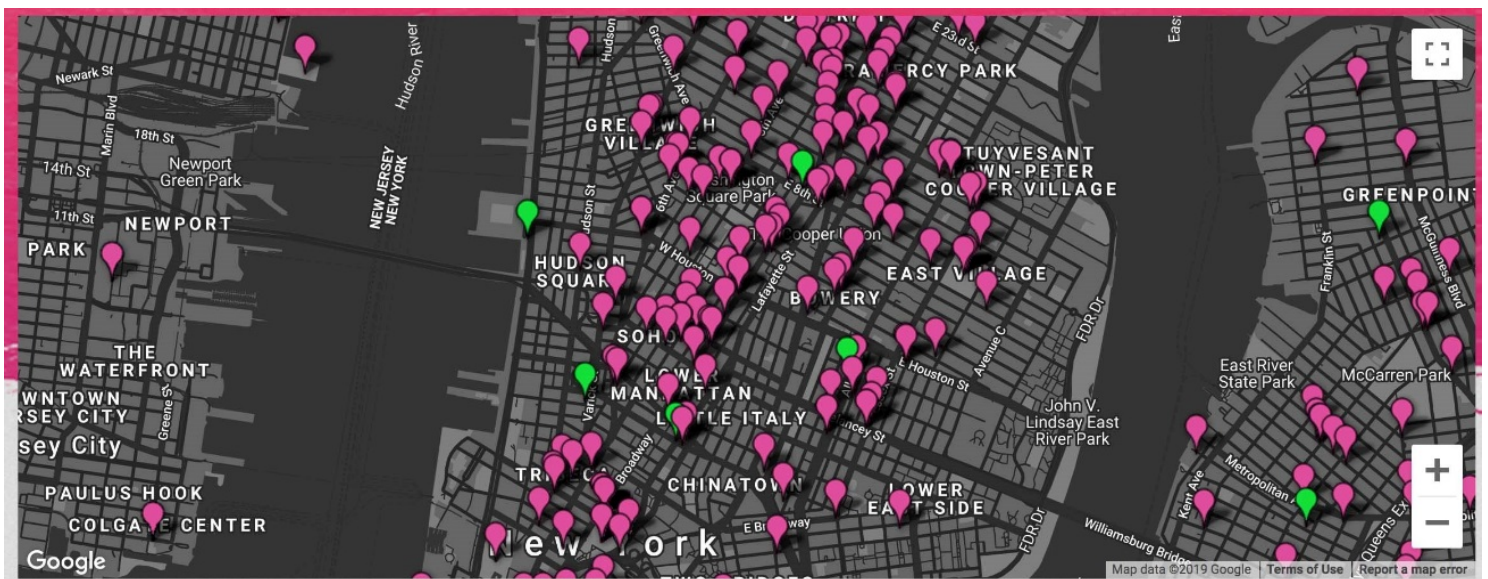

Figure 3. Screenshot of the Hollaback! NYC interactive Google Map.

Theo Kindynis (2014, p. 230) critiqued traditional approaches to crime mapping on the basis that it has the effect of "rendering the city as an urban dystopia - a 'threatscape', depicted solely in terms of criminality". The production of the "threatscape" is intimately interconnected with the construction of crime as decontextualized "points on a map", heightening a sense of fear in public spaces, producing certain areas as "no go zones", and eliding factors that may enhance or mitigate our actual risk of victimisation. Such mapping techniques, Kindynis suggests, run the risk of justifying the use of streetlevel policing and "law and order" approaches to governing crime. Hollaback! arguably retains aspects of these features, notably through its use of "points on a map" in documenting street harassment. Depending on how this material is engaged with, one reading would suggest that the Google map feature of the Hollaback! site reproduces some of the less desirable features of traditional crime mapping, whereby "points on a map" come to represent a fixed and "objective" representation of harm in public space, rather than itself working to produce a particular understanding of street harassment as a category of harmful behaviour. However, these more positivist tendencies are countered by other features of the Hollaback! site, particularly the ability to read detailed accounts of contributors' experiences, moving beyond the decontextualized approach of traditional crime maps. Given that the mapping of street harassment itself is an act of contestation and "mapping from below", this suggests that street harassment activism may function in inherently paradoxical and unstable ways that simultaneously reproduce and destabilise dominant power relations and "ways of knowing" vis-a-vis cartographic practices.

In contrast, the affordances of Instagram may allow @catcallsofnyc and @dearcatcallers to avoid generating the "threatscape" of traditional cartographies, with both accounts mapping street harassment in public space in an amorphous way where it is difficult to pinpoint or determine the precise geographic location. In both accounts, space is represented through series of photographs rather than "points on a map". In the case of @catcallsofnyc, these images feature only the sidewalk, with identifiable landmarks or locational devices typically not represented. In contrast, @dearcatcallers maps public space through a series of encounters with perpetrators, with Jansma and her perpetrator(s) foregrounded in each image. Yet, paradoxically, these amorphous representations of space might have the effect of generating all public space as a 
threatscape, particularly as they solely construct public space in and through encounters of street harassment.

Of course, this also raises the question of how the image is read and interpreted by others, as this is not a "neutral" or self-evident process (Kitchin and Dodge 2007). This points to the centrality of accounting not just for the affordances of platforms, but how the user engages with and makes sense of them: the production of the "threatscape" is a relational and iterative practice. Returning to the example of Hollaback!, this site has the potential to function as a "threatscape", with all urban space rendered potentially hostile and dangerous, particularly if emphasis is placed on viewing the Google map. Yet, a reading of this map in conjunction with submissions to the site and resources provided on the page may produce a different picture - perhaps one peppered with moments of resistance, bystander support and collective solidarity, rather than perpetual and allencompassing threat.

\subsection{Reproducing the map?}

The discussion so far has examined how online activism for street harassment can function as a form of counter-mapping that contests and subverts both dominant understandings of street harassment and the production of public space. At the same time, I have begun to point to the uncomfortable and contradictory ways in which these practices operate to reproduce dominant relations of power and ways of knowing or representing harm. In this final section, I aim to further critique and complicate the potential of the three sites to function as counter-maps.

A central question here is whose and which experiences of street harassment are captured in these mapping practices? In at least some respects, each of these sites works to map street harassment in limited or partial ways that intersect with broader concerns around the "digital divide". For instance, @dearcatcallers centres the experiences of a conventionally attractive young woman who was able to generate significant social and mainstream media attention to her efforts (Boyd 2017). Given the well-documented disparities in use of social media platforms for feminist and other activism (Bittner et al. 2013, Bittner 2016, Fileborn and Loney-Howes 2020), this suggests that the experiences mapped through these sites may tend to represent those of individuals who occupy a position of relative privilege.

Notably, many of the perpetrators documented through @dearcatcallers are men of colour, or who display signifiers of being working class (for example, men who are visibly employed in trades). The effect of this may be to perpetuate the trope of the sexually "dangerous" black man, or construct perpetrators as disproportionately stemming from marginalised backgrounds, working to further "other" these men as deviant. Other research on sexual violence has illustrated that women of colour can be reluctant to report men from within their own communities who perpetrate, in order to avoid reproducing these stereotypes or providing fuel for state intervention and surveillance (Willis 2011, Kagal et al. 2019). Similar barriers may be at play in shaping which and whose experiences are represented through these counter-maps, rendering these maps replete with silences. The dominant framing of individual perpetrators in the @dearcatcallers account may also work to produce perpetration as a problem of individually "aberrant" or "deviant" men, while failing to situate their actions within 
broader power structures and norms of masculinity. As such, while these counter-maps may disrupt particular norms and gendered power relations, they may simultaneously reinforce others in relation to race and class in this instance. Additionally, while the ability to contribute data towards these counter-maps is relatively democratic (the previous critique notwithstanding), Bittner and colleagues remind us that the design and affordances of these digital spaces are themselves rarely so. In other words, contributors to counter-mapping efforts may be limited in what they are able to contribute, with robust democratization only "achieved if the respective technologies can be modified (...) by users to serve their own interests" (Bittner et al. 2013, 936).

It is similarly important to question which forms of harassment are represented through these practices. As Heiden (2018, p. 66) suggests, "what a map does not show is often as important and powerful as what it does show", and it is for this reason we must remain attuned to the omissions and silences contained in counter-mapping practices (see also Parker 2006, Kim 2015, Reiz et al. 2017). For instance, certain forms of harassment may be easier to capture or represent in the chalk-writings of @catcallsofnyc, which tend to centre on more "tangible" instances of harassment (verbal comments). It is less certain how more ambiguous or subtle forms of harassment - such as prolonged, unwanted, but otherwise inoffensive conversation, or staring - might be captured and mapped effectively in this way. In other words, we need to ask what cannot be captured in this mode of representation? As I have argued elsewhere (Fileborn 2018), disclosure is an epistemological process through which street harassment becomes known in limited and partial ways. For instance, for some individuals, street harassment was such a common experience that it became background noise in their daily lives, quickly forgotten about and not shared with others. Other incidents were seen as too minor, trivial or mundane to consider sharing, while for others the trauma of "bigger" incidents made them too difficult to share. Such factors are likely to also shape what is seen as "worth" mapping online. Additionally, in the case of digital counter-mapping, street harassment is made "knowable" in a way that is shaped and delimited by the affordances and dominant vernaculars of these sites (Mendes et al. 2018), though these features are also what contributes towards the ability of these sites to function as counter-maps. While they may disrupt and contest dominant modes of knowledge production, we are still left with limited and partial "maps" of harassment that (re)produces and perpetuates other relations of power and inequality. Harassment is constructed in particular, limited ways in and through these practices, with subsequent implications for how the "problem" of harassment is articulated and responded to. This suggests that counter-maps are always themselves partial, contested and in a process of becoming (Kitchin and Dodge 2007, Bittner et al. 2013).

There is also the question of who these sites are for. Given that digital activism has been critiqued as "preaching to the converted" (Fileborn 2017), and the affordances of social media sites often function to create echo chambers that reinforce our worldview (Wood 2017), it is questionable to what extent each of these sites reaches a broad or diverse enough audience to genuinely disrupt or challenge dominant constructions of street harassment and/or public space. That said, given there has been some mainstream movement on the issue, such as the introduction of legislation and reporting hotlines, this does suggest some success at generating change. However, this might be conflating the question of whether these sites can be considered counter-maps with the question of 
whether these sites are effective at generating broader change. Nonetheless, this aspect of digital spaces suggests that street harassment counter-maps may be limited in their ability to truly disrupt the production of public space (Parker 2006).

Relatedly, we must ask what outcome(s) are achieved or generated through these activist efforts. As Kindynis (2014, p. 223) has argued, we must "remain vigilant against cartographies of intolerance and vindictiveness". The aims and goals of these sites are often vague or ambiguous (e.g., "raising awareness"), with little articulation of what one might do once "awareness" has been raised, or how we might progress towards goals such as ending street harassment. How these activist efforts are interpreted and taken up by others (particularly those in positions of power) is far from certain. In other words, we should not become complacent in our use and interpretation of counter-maps: even practices that are ostensibly working towards achieving some form of social justice may reflect or perpetuate other vested interests and relations of power (see also Parker 2006). There is potential for counter-mapping to contribute towards increased state surveillance and control, illustrated through the punitive criminal justice responses to street harassment being adopted in some jurisdictions. While there has been limited analysis of jurisdictions in which criminal justice mechanisms have been introduced to regulate street harassment, it is certainly plausible that these measures could be used disproportionately against perpetrators from marginalised backgrounds who are already subject to state intervention, over-regulation and surveillance (e.g., men of colour, the homeless, young people - see Fileborn and Vera-Gray 2017). Alternatively, these counter-maps may unintentionally play a role in responsibilising women and queer communities for their own safety in public spaces, rather than (or alongside) justifying state intervention and regulation (see also Kindynis 2014). For instance, these digital repositories have the potential to communicate to viewers "no go zones" which present a heightened risk of encountering harassment. Engagement with these sites may simply reinforce the need to use safety strategies and precautionary routines in public spaces, rather than working to transform or unsettle the conditions underpinning street harassment.

Finally, we currently know exceedingly little about how the users of these sites engage with and encounter this material. This is important in considering the extent to which these activist sites may reproduce a "threatscape". This critique is especially pertinent to Hollaback!, given that its mapping function most closely resembles the traditional "hotspots" of crime. However, the affordances of these platforms vary greatly, meaning the content is consumed and encountered in very different ways. There remain important - and unanswered - questions regarding how this material is consumed, and how the intensity of any impacts might be shaped by an array of factors including identity, emotional/affective states, temporality, the space/place of consumption and so forth. For example, an Instagram user scrolling through their main feed might have the occasional anti-street harassment post pop up, but they could also go to the account page and "binge" consume this content. The different accounts also vary in how identifiable public spaces are, as outlined earlier, and it is unclear how this might shape our experiences within public space as a result. Regardless, at present we simply do not know how women and queer people view and consume this material, or how they interpret it. These counter-maps could be reassuring, a form of consciousness-raising and solidarity, as well as generating a sense of fear when navigating urban space. They 
may do some, none, or all of these things, and experiences of engaging with this material are likely fluid. It may ultimately be more productive to understand these countermapping practices as "both/and", rather than "either/or" (Barker and Iantaffi 2019).

\section{Conclusion}

This article set out to examine the potential of three digital anti-street harassment activist efforts to function as a form of countermapping, taking up Kindynis' (2014) call for criminologists to engage critically with cartographies of crime, but also to examine their potentially emancipatory nature. Through a close reading of these case studies, I have argued that online anti-street harassment can be understood as a form of "countermapping" in multiple respects. This extends current scholarship on online activism and informal, victim-centred justice by considering how these practices are also situated in relation to broader questions of social and spatial justice. Making the spaces of street harassment visible is vital in drawing attention to the need for "spatial justice" something that is largely ignored in our dominant constructions of "justice" in response to gendered violence (Fileborn 2020). These accounts, to varying extents, work to disrupt the dominant ordering of public spaces. In doing so, they have the capacity to open up possibilities of "becoming" or transformation of public spaces. Each of the case studies additionally challenges and disrupts dominant modes of measuring and documenting "crime", through their circumvention of state/criminal justice definitions, and active reframing of a phenomenon constructed as "trivial" in dominant discourse. However, the extent to which these practices constitute countermapping is complex and contested: arguably, each of these sites simultaneously functions to challenge and reinforce existing power relations, and the production of space as a gendered "threatscape". Finally, I suggest there is a clear need for empirical research examining how users consume, interact with and experience these activist sites. In closing, it is my hope that this work has furthered Kindynis' (2014) contributions through demonstrating the generative possibilities of bringing critical cartographies and criminology in conversation with each other, continuing to open up the need to take the spatial elements of crime seriously, while avoiding reductive approaches.

\section{References}

Ahmed, S., 2017. Living a feminist life [online]. Durham: Duke University Press. Available from: https://doi.org/10.1215/9780822373377 [Access 23 January 2020].

Allen, T., and Queen, S., 2015. Beyond the map: Unpacking critical cartography in the digital humanities. Visible Language [online], 49(3), 79-98. Available from: https://design.ncsu.edu/co-lab/wp-content/uploads/2015/12/Visible-LanguageCM-2015-Allen-Queen-78-99.pdf [Access 23 January 2020].

Barker, M.J., and Iantaffi, A., 2019. Life Isn't Binary: On Being Both, Beyond, and InBetween. London/Philadelphia: Jessica Kingsley.

Bartlett, L., and Vavrus, F., 2017. Rethinking Case Study Research: A Comparative Approach [online]. New York: Routledge. Available from: https://doi.org/10.4324/9781315674889 [Access 23 January 2020]. 
Bittner, C., 2016. OpenStreetMap in Israel and Palestine - "game changer" of reproducer of contested cartographies? Political Geography [online], 57, 34-48. Available from: https://doi.org/10.1016/j.polgeo.2016.11.010 [Access 23 January 2020].

Bittner, C., Glasze, G., and Turk, C., 2013. Tracing contingencies: Analysing the political in assemblages of web 2.0 cartographies. Geo Journal [online], 78(6), 935948. Available from: https://doi.org/10.1007/s10708-013-9488-8 [Access 23 January 2020].

Boyd, P.J., 2017. Oi you! Catcallers and street harassers - your time is nearly up. The Guardian [online], 28 November. Access 4 October 2019. Available from: https://www.theguardian.com/commentisfree/2017/nov/27/catcall-streetharassment-misogyny-metoo-girls-women-misogyny [Access 23 January 2020].

Clark, H., 2010. "What is the justice system willing to offer?" Understanding sexual assault victim/survivors' criminal justice needs. Family Matters [online], no 85, 2837. Available from: https://aifs.gov.au/publications/family-matters/issue-85/whatjustice-system-willing-offer [Access 23 January 2020].

Clark, H., 2015. A fair way to go: Justice for victim-survivors of sexual violence. In: A. Powell, N. Henry and A. Flynn, eds., Rape Justice: Beyond the Criminal Law [online]. London: Palgrave Macmillan, 18-35. Available from: https://doi.org/10.1057/97811374761592 [Access 23 January 2020].

Crampton, J.W., 2009. Cartography: Performative, participatory, political. Progress in Human Geography [online], 33(6), 840-848. Available from: https://doi.org/10.1177/0309132508105000 [Access 23 January 2020].

Crampton, J.W., and Krygier, J., 2005. An introduction to critical cartography. ACME: An International E-Journal for Critical Geographies [online], 4(1), 11-33. Available from: https://acme-journal.org/index.php/acme/article/view/723 [Access 23 January 2020].

Dalton, C., and Mason-Deese, L., 2012. Counter (mapping) actions: Mapping as militant research. ACME: An International E-Journal for Critical Geographies [online], 11(3), 439-466. Available from: https://www.acmejournal.org/index.php/acme/article/view/941 [Access 23 January 2020].

Daly, K., 2014. Reconceptualising sexual victimisation and justice. In: I. Vanfraechem, A. Pemberton and F.M. Mdahinda, eds., Justice for Victims: Perspectives on Rights, Transition and Reconciliation. Oxon: Routledge, 378-395.

Davis, D., 1994. The harm that has no name: Street harassment, embodiment, and African American women. UCLA Women's Law Journal [online], 4, 133-178. Available from: https://escholarship.org/uc/item/83b9f21g [Access 23 January 2020].

dearcatcallers [@dearcatcallers], 2017. [Instagram post]. Instagram [online], 29 August. Available from: https://www.instagram.com/p/BYYSF 1ljQp/ [Access 4 October 2019]. 
Dhillon, M., and Bakaya, S., 2014. Street harassment: A qualitative study of the experiences of young women in Delhi. SAGE Open [online], 20 July. Available from: $\underline{\text { https://doi.org/10.1177/2158244014543786 }}$

Fairchild, K., 2010. Context effects on women's perceptions of stranger harassment. Sexuality $\mathcal{E}$ Culture [online], 14, 191-216. Available from: https://doi.org/10.1007/s12119-010-9070-1 [Access 23 January 2020].

Fanghanel, A., 2019. Disrupting Rape Culture: Public Space, Sexuality and Revolt [online]. Bristol University Press. Available from: https://doi.org/10.1332/policypress/9781529202526.001.0001 [Access 23 January 2020].

Fileborn, B., 2014. Online justice and street harassment: Digital justice or shouting into the ether? Griffith Journal of Law \& Human Dignity [online], 2(1), 32-51. Available from: https://griffithlawjournal.org/index.php/gjlhd/article/view/569 [Access 23 January 2020].

Fileborn, B., 2017. Justice 2.0: Street harassment victims' use of social media and online activism as sites of informal justice. The British Journal of Criminology [online], 57(6), 1482-1501. Available from: https://doi.org/10.1093/bjc/azw093 [Access 23 January 2020].

Fileborn, B., 2018. Naming the unspeakable harm of street harassment: A survey-based examination of disclosure practices. Violence Against Women [online], epub ahead of print. Available from: https://doi.org/10.1177\%2F1077801218768709

Fileborn, B., 2020. Embodied geographies: Navigating street harassment. In: J. Berry et al., eds., Contentious Cities: Design and the Gendered Production of Space. London: Routledge.

Fileborn, B., and Loney-Howes, R., 2020. Using Social Media to Resist Gender Violence: A Global Perspective. In: E. Erez and P. Ibarra, eds., Oxford Encyclopedia of International Criminology [online]. Published online in June 2020. New York/Oxford: Oxford University Press. Available from: https://doi.org/10.1093/acrefore/9780190264079.013.613 [Access 28 July 2020].

Fileborn, B., and Vera-Gray, F., 2017. "I want to be able to walk the street without fear": Transforming justice for street harassment. Feminist Legal Studies [online], 25(2). Available from: https://doi.org/10.1007/s10691-017-9350-3 [Access 23 January 2020].

Fogg-Davis, H.G., 2006. Theorizing Black lesbians within Black feminism: A critique of same-race street harassment. Politics $\mathcal{E}$ Gender [online], 2, 57-76. Available from: https://doi.org/10.1017/S1743923X06060028 [Access 23 January 2020].

Hayward, K.J., 2012. Five spaces of cultural criminology. The British Journal of Criminology [online], 52(3), 441-462. Available from: https://doi.org/10.1093/bjc/azs008 [Access 23 January 2020].

Heiden, W., 2018. Coopting cops with maps: The rhetorical power of cartography in modern policing. Cartographica [online], 53(1), 62-71. Available from: https://doi.org/10.3138/cart.53.1.2017-0026 [Access 23 January 2020]. 
Henry, N., and Powell, A., 2015. Embodied harms: Gender, shame, and technologyfacilitated sexual violence. Violence Against Women [online], 21(6), 758-779. Available from: https://doi.org/10.1177/1077801215576581 [Access 23 January 2020].

Herman, J., 2005. Justice from the victim's perspective. Violence Against Women [online], 11(5), 571-602. Available from: https://doi.org/10.1177/1077801205274450 [Access 23 January 2020].

Johnson, M., and Bennett, E., 2015. Everyday Sexism: Australian Women's Experiences of Street Harassment. Melbourne: The Australia Institute.

Kagal, N., Cowan, L., and Jawad, H., 2019. Beyond the bright lights: Are minoritized women outside the spotlight able to say \#MeToo? In: B. Fileborn and R. LoneyHowes, eds., \#MeToo and the Politics of Social Change [online]. London: Palgrave Macmillan, 133-149. Available from: https://doi.org/10.1007/978-3-030-15213-0 9 [Access 23 January 2020].

Kern, L., 2005. In place and at home in the city: Connecting privilege, safety and belonging for women in Toronto. Gender, Place \& Culture [online], 12, 357-377. Available from: https://doi.org/10.1080/09663690500202590 [Access 23 January 2020].

Kim, A.M., 2015. Critical cartography 2.0: From "participatory mapping" to authored visualizations of power and people. Landscape and Urban Planning [online], 142, 215-225. Available from: https://doi.org/10.1016/j.landurbplan.2015.07.012 [Access 23 January 2020].

Kindynis, T., 2014. Ripping up the map: Criminology and cartography reconsidered. British Journal of Criminology [online], 54, 222-243. Available from: https://doi.org/10.1093/bjc/azt077 [Access 23 January 2020].

Kissling, E.A., 1991. Street harassment: The language of sexual terrorism. Discourse $\mathcal{E}$ Society, 2(4), 451-460.

Kitchin, R., and Dodge, M., 2007. Rethinking maps. Progress in Human Geography [online], 31(3), 331-344. Available from: https://doi.org/10.1177/0309132507077082 [Access 23 January 2020].

Laniya, O.O., 2005. Street smut: Gender, media, and the legal power dynamics of street harassment, or "hey sexy" and other verbal ejaculations. Columbia Journal of Gender and Law, 14(1), 91-130.

Lenton, R., et al., 1999. Sexual harassment in public places: Experiences of Canadian women. Canadian Review of Sociology [online], 36, 517-540. Available from: https://doi.org/10.1111/j.1755-618X.1999.tb00962.x [Access 23 January 2020].

Loney-Howes, R., 2019. The politics of the personal: The evolution of anti-rape activism from second-wave feminism to \#MeToo. In: B. Fileborn and R. Loney-Howes, eds., \#MeToo and the Politics of Social Change [online]. London: Palgrave Macmillan, 21-35. Available from: https://doi.org/10.1007/978-3-030-15213-0 2 [Access 23 January 2020]. 
Maharawal, M.M., and McElroy, E., 2018. The anti-eviction mapping project: Counter mapping and oral history toward Bay Area housing justice. Annals of the American Association of Geographers [online], 108(2), 380-389. Available from: https://doi.org/10.1080/24694452.2017.1365583 [Access 23 January 2020].

Markham, A., and Buchanan, E., 2012. Ethical decision-making and Internet research: Recommendations from the AoIR Ethics Working Committee (Version 2.0) [online]. Association of Internet Researchers. Available from: http://aoir.org/reports/ethics2.pdf [Access 23 January 2020].

Mason, G., 1993. Violence Against Lesbians and Gay Men: Violence Prevention Today $n^{o} .2$. Canberra: Australian Institute of Criminology.

McGlynn, C., 2011. Feminism, rape and the search for justice. Oxford Journal of Legal Studies [online], 31, 825-842. Available from: https://doi.org/10.1093/ojls/gqr025 [Access 23 January 2020].

McLafferty, S., 2005. Women and GIS: Geospatial technologies and feminist geographies. Cartographica [online], 40(4), 37-45. Available from: https://doi.org/10.3138/1341-21JT-4P83-1651 [Access 23 January 2020].

Mendes, K., Keller, J., and Ringrose, J., 2018. Digitized narratives of sexual violence: Making sexual violence felt and known through digital disclosures. New Media $\mathcal{E}$ Society [online], online first, 1-21. 29 December. Available from: https://doi.org/10.1177/1461444818820069 [Access 23 January 2020].

Mendes, K., Ringrose, J., and Keller, J., 2019. Digital Feminist Activism: Girls and Women Fight Back Against Rape Culture. Oxford University Press.

Nielsen, L.B., 2000. Situating legal consciousness: Experiences and attitudes of ordinary citizens about law and street harassment. Law \& Society Review [online], 34, 10551090. Available from: https://doi.org/10.2307/3115131 [Access 23 January 2020].

NYC Hollaback, no date. Share your story. NYC Hollaback [online]. Available from: https://nyc.ihollaback.org/share-your-story/ [Access 6 February 2020].

O'Neill, T., 2018. “Today I speak": Exploring how victim-survivors use Reddit. International Journal for Crime, Justice and Social Democracy [online], 7(1), 44-59. https://doi.org/10.5204/ijcjsd.v7i1.402 [Access 23 January 2020].

Parker, B., 2006. Constructing community through maps? Power and praxis in community mapping. The Professional Geographer [online], 58(4), 470-484. Available from: https://doi.org/10.1111/j.1467-9272.2006.00583.x [Access 23 January 2020].

Plan International and OurWatch, 2016. A Right to the Night: Australian Girls on Their Safety in Public Places [online]. Melbourne: Plan International Australia \& OurWatch. Available from: https://www.plan.org.au/learn/who-weare/blog/2016/05/12/a-right-to-the-night [Access 23 January 2020].

Plan International, 2018. Unsafe in the City: Research into the Everyday Experiences of Girls and Young Women [online]. Report. Surrey: Plan International. Available from: https://plan-international.org/unsafe-city [Access 23 January 2020]. 
Powell, A., 2015. Seeking rape justice: Formal and informal responses to sexual violence through technosocial counter-publics. Theoretical Criminology [online], 19(4), 571-588. Available from: https://doi.org/10.1177/1362480615576271 [Access 23 January 2020].

Reiz, N., O'Lear, S., and Tuininga, D., 2017. Exploring a critical legal cartography: Law, practice, and complexities. Geography Compass [online], 12e, 1-10. Available from: https://doi.org/10.1111/gec3.12368 [Access 23 January 2020].

Salovaara, I., 2016. Participatory maps. Digital Journalism [online], 4(7), 827-837. Available from: https://doi.org/10.1080/21670811.2016.1173519 [Access 23 January 2020].

Salter, M., 2013. Justice and revenge in online counter-publics: Emerging responses to sexual violence in the age of social media. Crime Media Culture [online], 9(3), 225242. Available from: https://doi.org/10.1177/1741659013493918 [Access 23 January 2020].

Serisier, T., 2018. Speaking Out: Feminism, Rape and Narrative Politics. London: Palgrave Macmillan.

Stop Street Harassment, no date. Street harassment and the law [online]. Available from: http://www.stopstreetharassment.org/strategies/sshlaw/ [Access 27 January 2020]

Stratton, G., Powell, A., and Cameron, R., 2017. Crime and justice in digital society: Towards a "digital criminology"? International Journal for Crime, Justice and Social Democracy [online], 6(2), 17-33. Available from: https://doi.org/10.5204/ijcjsd.v6i2.355 [Access 6 February 2020].

Swanborn, P., 2010. Case Study Research: What, Why and How? [online]. Thousand Oaks: Sage. Available from: https://doi.org/10.4135/9781526485168 [Access 23 January 2020].

Tuerkheimer, D., 1997. Street harassment as sexual subordination: The phenomenology of gender-specific harm. Wisconsin Women's Law Journal, 12, 167-206.

Vera-Gray, F., 2016. Men's Intrusion, Women's Embodiment: A Critical Analysis of Street Harassment. London/New York: Routledge.

Vera-Gray, F., 2018. The Right Amount of Panic: How Women Trade Freedom for Safety [online]. Bristol: Polity Press. Available from: https://doi.org/10.2307/j.ctv301drp [Access 23 January 2020].

Vera-Gray, F., and Fileborn, B., 2018. Recognition and the harms of "cheer up". The Philosophical Journal of Conflict and Violence [online], 2(1), 78-96. Available from: https://doi.org/10.22618/TP.PICV.20182.1.171005 [Access 23 January 2020].

Willis, M., 2011. Non-disclosure of violence in Australian Indigenous communities. Trends $\mathcal{E}$ Issues in Crime and Criminal Justice [online], no 405. Canberra: Australian Institute of Criminology. Available from: https://www.aic.gov.au/publications/tandi/tandi405 [Access 23 January 2020].

Wood, M., 2017. Antisocial Media: Crime-Watching in the Internet Age. London: Palgrave Macmillan. 